\title{
SEROTYPIC CHARACTERIZATION OF SALMONELLA ISOLATES IN MEAT AND POULTRY PRODUCTS
}

\author{
MOHAMED KARMI \\ Department of Food Hygiene, Faculty of Veterinary Medicine, Aswan University, 81528 Aswan, Egypt. \\ Email: Karmy99@yahoo.com, mkarmi@aswu.edu.eg.
}

\section{ABSTRACT}

Received at: $28 / 1 / 2014$

A total of 100 meat and poultry products samples were collected from shops and supermarkets in Aswan governorate; including 50 meat products samples and 50 poultry products. Samples were collected to determine the serotypes and antigenic structures of Salmonella isolates in meat and poultry products and to study the correlation between serotypes and type of meat. Salmonella was isolated by conventional methods and serotyping of Salmonella isolates was performed by slide

Accepted: 8/3/2014 agglutination method using antisera to Salmonella. It was observed that $16 \%$ of samples were positive for Salmonella; $26 \%(13 / 50)$ in meat samples and 6\% (3/50) in poultry samples. Serotypes of isolated Salmonella were Salmonella enteritidis $6.25 \%$ (1/16), Salmonella newland 18.75\% (3/16), Salmonella Kentucky 12.5\% (2/16), Salmonella heifa $6.25 \%$ (1/16), Salmonella bron 6.25\% (1/16), Salmonella rissens 12.5\% (2/16), Salmonella fortune 12.5\% (2/16), Salmonella agona 6.25\% (1/16), Salmonella hessarek 6.25\% (1/16), Salmonella hoboken 6.25\% (1/16), Salmonella veneziana 6. Meat and poultry products were contaminated with pathogenic Salmonella and the more prevalent serotypes were Salmonella newland, Salmonella rissens, Salmonella fortune, Salmonella Kentucky and the lesser prevalent isolates were Salmonella enteritidis, Salmonella heifa, Salmonella bron, Salmonella agona, Salmonella hessarek, Salmonella hoboken and Salmonella veneziana. Results showed that minced meat, kofta, liver and gizzard and sheeshtawook were more contaminated with Salmonellae. Meat and poultry products considered an important source of high risk serotypes of Salmonellae for human and hygienic measures should be undertaken to reduce contamination of meat and poultry products with Salmonella.

Keywords: Salmonella, serotyping, meat, poultry products.

\section{INTRODUCTION}

Salmonellae are zoonotic bacteria of public health significance, with considerable economic impact (Molina-Lopez et al., 2011). Salmonellosis is one of the most common and widely distributed food borne diseases. In Europe, Salmonellosis is the second food borne disease after campylobacteriosis, in Italy; Salmonella is still the major cause of food borne outbreaks (Botti et al., 2013; European Food Safety Authority, 2012). The genus Salmonellae consists of two species: Salmonella enteric and Salmonella bongori. The first one includes 6 subspecies (subsp): enterica, salamae, arizona, diarizona, houtenae and indica. There are over 2,500 serotypes of zoonotic Salmonella, most belonging to the subspecies enterica (Office International des Epizooties, 2010). Salmonellae belonging to the family Enterobacteriaceae are classified and identified into serotypes according to the KauffmannWhite scheme 7, which currently contains more than 2000 serotypes (Williams and Wilkins, 1984).
Serotyping using the widely accepted KauffmannWhite scheme is central to the epidemiological classification of Salmonella strains and thus to surveillance studies, to identify trends in disease transmission, and for detection of outbreaks. Nevertheless, in recent years there is a tendency to use DNA-based methods to replace or augment serological testing, and such methods may be used as a basis to define strains as serovar $(4,[5], 12: \mathrm{i})$ or Typhimurium (Echeita et al., 2002; Tennant et al., 2010; Barco et al., 2010).

Ninety-seven percent of food samples were contaminated with at least one enteric pathogen, Salmonella spp. is one of the most commonly isolated pathogen about $84 \%$. Fifty-one percent of children infected with Salmonella spp, infected with the same serotypes isolated from meat samples, suggesting this pathogen is widespread in food and humans (Bodhidatta et al., 2013). In 2007 Austria reported a total of 438 food borne outbreaks, 
Salmonella caused $70 \%$ of the bacterial outbreaks and the most implicated food was the poultry meat products (Much et al., 2007).

Strains of Salmonellae isolated from poultry and products are strongly associated with multi-locus sequence type ST28 and showed antimicrobial multiresistance profiles, so that poses a health risk to consumers (Toboldt et al., 2012). Pulsed-field gel electrophoresis (PFGE) results confirmed occurrence of similar salmonella genotypes in both poultry meat products and humans, also, antimicrobial drug resistance profiles suggesting possible transmission of resistance from meat to humans (Oloya et al., 2009). In the last two decades, Salmonella enterica serotype Enteritidis has become one of the main agents causing food borne diseases worldwide. This agent is transmitted mainly by contaminated meat and poultry products $(88 \%)$, suggesting strong relationships between cases of salmonella related to human illness and salmonella positive in meat and poultry products (Rios et al., 2009; Chen et al., 2008; Pang et al., 2007).

\section{MATERIALS and METHODS}

Collection of samples: A total of 100 meat and poultry products samples were collected from shops and supermarkets in Aswan governorate; including 50 meat products samples and 50 poultry products. Samples were collected in sterile polyethylene bags, put in ice box under low temperature and transported to the laboratory for bacteriological examination.

Preparation of samples: Twenty five $g$ meat was taken from each poultry meat product sample in sterile stomacher bag, mixed with $225 \mathrm{ml}$ buffered peptone water (BPW) (Oxoid Limited, Hampshire, England) and homogenized by using Stomacher ${ }^{\circledR}$ 400 Circulator (Seward Ltd., UK).

Isolation and Identification: The samples mixtures incubated at $37^{\circ} \mathrm{C}$ for 18 hours, $0.1 \mathrm{ml}$ mixture was transferred to $10 \mathrm{ml}$ Rappaport-Vassiliadis (RV) medium, vortexed and incubated for $24 \pm 2 \mathrm{~h}$ at $42 \pm$ $0.2^{\circ} \mathrm{C}$ (circulating, thermostatically-controlled, water bath). $3 \mathrm{~mm}$ loopful $(10 \mu \mathrm{l})$ of each incubated tube was streaked on Xylose Lysine Desoxycholate (XLD) agar and incubated for $24 \pm 2 \mathrm{~h}$ at $35^{\circ} \mathrm{C}$. Typical colonies of Salmonella were pink colonies with or without black centers. Many cultures of Salmonella may produce colonies with large, glossy black centers or may appear as almost completely black colonies. Salmonella isolates were confirmed by biochemical tests as Triple Sugar Iron agar (TSI), Lysine decarboxylase (LIA), Urease, Indole, Methyl red, Voges-Proskauer and Simmons citrate (Ewing, 1986; June et al., 1995; Hammack et al., 1999; June et al., 1999; Hammack et al., 2001).
Serotyping of bacterial isolates: Positive Salmonella isolates were tested for presence of somatic $(\mathrm{O})$ and flagellar $(\mathrm{H})$ antigens using slide agglutination test. $3 \mathrm{~mm}$ loopful of culture from 24$48 \mathrm{~h}$ tryptose blood agar base (without blood) was emulsified with $2 \mathrm{ml} 0.9 \%$ saline. One drop of culture suspension was adding to upper portion of each slide. One drop of saline solution was adding to lower part of the slide. One drop of Salmonella monovalent somatic (O) antiserum was adding to other section only. With clean sterile transfer loop or needle, mix culture suspension with saline solution for one section and repeat for other section containing antiserum. Tilt mixtures in back-and-forth motion for $1 \mathrm{~min}$ and observe against dark background in good illumination. Consider any degree of agglutination a positive reaction. Classify monovalent somatic $(\mathrm{O})$ test results as follows: (a) Positive - agglutination in test mixture; no agglutination in saline control (b) Negative - no agglutination in test mixture; no agglutination in saline control (c) Nonspecific - agglutination in test and in control mixtures. For the flagellar $(\mathrm{H})$ antigen test, repeat the previous steps and test with Salmonella monovalent flagellar $(\mathrm{H})$ antisera instead of Somatic (o) antisera (AOAC, 2000). A Complete serological identification of salmonella isolates were done according to Kauffman-White classification Scheme (Murray et al., 1995; Grimont, 2013; Chiou et al., 2006; Popoff, 2001).

\section{RESULTS}

It was observed that $16 \%$ of samples were positive for Salmonellae; $26 \%(13 / 50)$ in meat samples and $6 \%(3 / 50)$ in poultry samples (Table 1). The identified Serotypes of isolated Salmonellae were Salmonella enteritidis $6.25 \%$ (1/16), Salmonella newland $18.75 \%$ (3/16), Salmonella Kentucky $12.5 \%$ (2/16), Salmonella heifa 6.25\% (1/16), Salmonella bron $6.25 \%$ (1/16), Salmonella rissens $12.5 \%$ (2/16), Salmonella fortune $12.5 \%$ (2/16), Salmonella agona $6.25 \%$ (1/16), Salmonella hessarek 6.25\% (1/16), Salmonella hoboken $6.25 \%(1 / 16)$ and Salmonella veneziana $6.25 \%(1 / 16)$ (Table 2). Results showed that higher rates of Salmonellae contamination were found in minced meat, kofta, liver and gizzard and sheeshtawook, while lower rates were found in luncheon, burgers, and smoked turkey. The most isolated serotype was Salmonella newland, then Salmonella rissens, Salmonella fortune, Salmonella Kentucky and the lesser prevalent isolates were Salmonella enteritidis, Salmonella heifa, Salmonella bron, Salmonella agona, Salmonella hessarek, Salmonella hoboken and Salmonella veneziana (Table 2). Antigenic structures of isolated Salmonellae were determined (Table 3). 
Assiut Vet. Med. J. Vol. 60 No. 141 April 2014

Table 1: Incidence of Salmonellae in meat and poultry products.

\begin{tabular}{cccc}
\hline Sample & Number & Positive & Incidence \\
\hline Meat Products & 50 & 13 & 26 \\
Poultry Products & 50 & 3 & 6 \\
\hline Total & 100 & 16 & 16 \\
\hline
\end{tabular}

Table 2: Incidence rate of Salmonella serotypes isolated from meat and poultry products.

\begin{tabular}{cccc}
\hline \multirow{2}{*}{ Salmonella Serotypes } & \multicolumn{2}{l}{ Incidence of Serotypes } & \multirow{2}{*}{ Type of meat or poultry product } \\
\cline { 2 - 3 } & Number & Rate (\%) & \\
\hline Salmonella newland & $3 / 16$ & 18.75 & \multirow{2}{*}{$\begin{array}{c}\text { Minced meat, meat burger, Meat } \\
\text { kofta }\end{array}$} \\
\hline Salmonella kentuckyn & $2 / 16$ & 12.5 & Livers \& gizzards, sheeshtawook \\
\hline Salmonella fortunes & $2 / 16$ & 12.5 & Minced meat, Meat kofta \\
\hline Salmonella rissens & $2 / 16$ & 12.5 & Minced meat, Meat kofta \\
\hline Salmonella enteritidis & $1 / 16$ & 6.25 & Meat kofta \\
\hline Salmonella haifa & $1 / 16$ & 6.25 & Meat burger \\
\hline Salmonella hessarek & $1 / 16$ & 6.25 & Minced meat \\
\hline Salmonella agona & $1 / 16$ & 6.25 & Meat kofta \\
\hline Salmonella hoboken & $1 / 16$ & 6.25 & Meat luncheon \\
\hline Salmonella veneziana & $1 / 16$ & 6.25 & Minced meat \\
\hline Salmonella bron & $1 / 16$ & 6.25 & \\
\hline
\end{tabular}

Table 3: Antigenic Structures of Salmonella serotypes isolated from meat and poultry products.

\begin{tabular}{cc}
\hline Salmonella Serotypes & Antigenic Structure \\
\hline Salmonella newland & $3,10(15,34) \mathrm{e}, \mathrm{h} ; \mathrm{e}, \mathrm{n}, \mathrm{x}$ \\
\hline Salmonella kentucky & $8,20, \mathrm{I}, \mathrm{z} 6$ \\
\hline Salmonella fortune & $1,4,12,27 ; \mathrm{z} 10, \mathrm{z} 6$ \\
\hline Salmonella rissens & 6,$7 ; 14 ; \mathrm{f}, \mathrm{g}$ \\
\hline Salmonella enteritidis & $1,9,12 ; \mathrm{g}, \mathrm{m}$ \\
\hline Salmonella haifa & $1,4,(5), 12 ; \mathrm{z} 10 ; 1,2$ \\
\hline Salmonella hessarek & $4,12,27 ; \mathrm{a} ; 1,5$ \\
\hline Salmonella agona & $1,4(5) ; 12 ; \mathrm{f}, \mathrm{g}, \mathrm{s} ;(1,2)$ \\
\hline Salmonella hoboken & 3,$10 ; \mathrm{I} ; \mathrm{I}, \mathrm{w}$ \\
\hline Salmonella veneziana & $11 ; \mathrm{I} ; \mathrm{e}, \mathrm{n}, \mathrm{x}$ \\
\hline Salmonella bron & 13,$22 ; \mathrm{g}, \mathrm{m} ;(\mathrm{e}, \mathrm{n}, \mathrm{z} 15)$ \\
\hline
\end{tabular}

\section{DISCUSSION}

The overall incidence of salmonella were $16 \%$ of samples; $26 \%(13 / 50)$ in meat products samples and $6 \%(3 / 50)$ in poultry products samples. The most common serotypes of salmonella were Salmonella newland, Salmonella Kentucky, Salmonella rissens and Salmonella fortune. These serotypes were isolated mainly from minced meat, kofta, meat burgers and sheeshtawook which have higher incidence of salmonella; $60 \%$ in kofta, $40 \%$ in minced meat, $20 \%$ in meat burgers and $20 \%$ in sheeshtawook samples. The most famous pathogenic serotypes Salmonella enteritidis was found in kofta samples. It is noticed that meat samples $(26 \%)$ were more contaminated with salmonella than poultry samples $(6 \%)$, so we can say that meat products are more risky for consumers. Also, results showed that meat and poultry products contain high variety of salmonella serotypes, about 11 different serotypes 
which can cause different pathogenic effects for human.

It is noteworthy that in 2009 the great majority of strains were collected from poultry $(45.7 \%)$, swine $(16.02 \%)$ and turkey $(4.14 \%)$ (Centro de Referenza Nazionale per le Salmonellosi, 2009). However, some genes encoding for virulence factors located on plasmids, can be transferred from one strain to another and can cause an increase in the pathogenicity of serotypes (Boyd and Hartl, 1997). Different serotypes can be present in different animal species: some of them are considered speciesspecific, while others are ubiquitous (Graziani et al., 2011). The presence of virolence plasmids in hostadapted serovars suggests that horizontal virulence acquisition can have expanded the host range of Salmonella (Rotger and Casadesus, 1999). In detection study 46 Salmonella strains were isolated from 42 meat samples; the positive rate was $20.1 \%$. The majority of positive samples were fresh meat, $69.23 \%$ in duck, $37.14 \%$ in chicken, $20 \%$ in beef and $16.67 \%$ in pork. The most common serotypes were Derby (21.74\%), Typhimurium (10.87\%), Enteritidis (8.7\%), Tshiongwe (8.7\%), Indiana (8.7\%) and Weltevreden $(8.7 \%)$. Salmonellae present in retail meats were common and phenotypically diverse (Yang et al., 2013). Differences between serogroups are related to polymorphism at a specific genome locus, the $\mathrm{O}$ antigen gene cluster, responsible for $\mathrm{O}$ antigen biosynthesis (Ovchinnikova et al., 2013).

In study of the structures and genetics of the $46 \mathrm{O}$ antigens of Salmonellae, a major pathogen of humans and domestic animals, found great variations in structures which underpin the serological specificity of the 46 recognized serogroups. Salmonellae O antigens can be divided into two major groups: $\mathrm{N}$ acetylglucosamine (GlcNAc) and Nacetylgalactosamine (GalNAc), the structures and gene clusters of the GlcNAc-/GalNAc-initiated $\mathrm{O}$ antigens were found to be highly diverse, and 24 of them were found to be identical or closely related to Escherichia coli O antigens ((Liu et al., 2013; Dziadziuszko et al., 2012). Salmonella enterica serovar Enteritidis colonises chickens usually without any gross clinical signs, however, inflammation can be recorded in the intestinal tract, caecum in particular (Matulova et al., 2012; Matulova et al., 2013-a; Matulova et al., 2013-b). In India, enteric fever is a major public health problem and Salmonella typhi is the most common aetiologic agent. Multilocus sequence typing (MLST) pattern grouped Salmonella typhi into two sequence typesST1 and ST2. ST1 was predominantly present followed by ST2 (Dahiya et al., 2013). In study of children suffering from gastrointestinal infection, 19 Salmonella enteritidis were isolated from 34 anus swab samples of suspected cases and the detection rate was $56 \%$. All of the 19 Salmonella enteritidis showed the same serological serotype, biochemical reaction, drug sensitivity and phage lysis pattern. The Salmonella enteritidis had the identical pulsed field gel electrophoresis (PFGE) pattern (100\% similarity), and were different from the pattern of local sporadic infection cases (Yang et al., 2013). Salmonella Typhimurium is the serovar most frequently isolated from persistently infected slaughter pigs in Europe, and its pathogenesis is host species specific (Van Parys et al., 2013; Hernandez et al., 2013). Study of occurrence and characterization of serological variant Salmonella Typhimurium revealed that monophasic Salmonella Typhimurium was found at low frequency in various sources along the food chain, including feed, animals, and meat and sewage sludge (Wasyl and Hoszowski, 2012; Hopkins et al., 2012).

Sero-incidence estimation is a new method to estimate and compare the incidence of salmonella infections in human populations independent of surveillance artefacts (Falkenhorst et al., 2012; Falkenhorst et al., 2013). Some authors see that serotyping is a classic method and should be replaced by a recent techniques such as multilocus sequence typing (MLST) that can be more capable to recognize evolutionary groups and strain relatedness (Achtman et al., 2012) and PCR assay (Beaubrun et al., 2012). Application of hygienic approaches and effectiveness of potential interventions during production, slaughtering, manufacturing, preparation and processing of poultry meat products can significantly reducing the number of salmonella positive samples in poultry meat products (Van der Fels-Klerx et al., 2008).

\section{CONCLUSION}

The results indicated that meat and poultry products contaminated with pathogenic Salmonellae and the more prevalent serotypes were Salmonella newland, Salmonella rissens, Salmonella fortune, Salmonella Kentucky and the lesser prevalent isolates were Salmonella enteritidis, Salmonella heifa, Salmonella bron, Salmonella agona, Salmonella hessarek, Salmonella hoboken and Salmonella veneziana. Results showed that minced meat, kofta, liver and gizzard and sheeshtawook were more contaminated with Salmonella. Meat and poultry products considered an important source of high risk serotypes of Salmonella for human and hygienic measures should be undertaken to reduce contamination of meat and poultry products with Salmonellae.

\section{ACKNOWLEDGEMENTS}

The author is thankful to the Faculty of Veterinary Medicine, Aswan University for financial support. 


\section{COMPETING INTERESTS}

The author declares that he has no competing interests.

\section{REFERENCES}

Achtman, M.; Wain, J.; Weill, F.X.; Nair, S.; Zhou, Z.; Sagal, V.; Krauland, M.G.; Hale, J.L.; Harbottle, H.; Uesbeck, A.; Dougan, G.; Harrison, L.H. and Brisse, S. (2012): Multilocus sequence typing as a replacement for serotyping in Salmonella enteric. PLoS Pathogens, 8 (6): e1002776.

AOAC International (2000): Official Methods of Analysis, 17th ed., Methods 967.25-967.28, 978.24, 989.12, 991.13, 994.04, and 995.20. AOAC International, Gaithersburg, MD.

Barco, L.; Lettini, A.A.; Ramon, E.; Longo, A.; Saccardin, C. and Pozza, M.C. (2011): A rapid and sensitive method to identify and differentiate Salmonella enteric serotype Typhimurium and Salmonella enteric serotype 4,5,12:i: - by combining traditional serotyping and multiplex chain reaction. Food borne pathog Dis, 8 (6): 741-743.

Beaubrun, J.G.; Cheng, C.M.; Chen, K.S.; Ewing, L.; Wang, H.; Agpaoa, M.C.; Huang, M.C.; Dickey, E.; Du, J.M.; Williams-Hill, D.M.; Hamilton, B.; Micallef, S.A.; Goldstein, R.E.; George, A.; Joseph, S.W.; Sapkota, A.R.; Jacobson, A.P.; Tall, B.D.; Kothary, M.H.; Dudley, K. and Hanes, D.E. (2012): The evaluation of a PCR-based method for identification of Salmonella enteric serotypes from environmental samples and various food matrices. Food Microbiol, 31(2): 199-209. doi: 10.1016/j.fm.2012.03.016.

Bodhidatta, L.; Srijan, A.; Serichantalergs, O.; Bangtrakulnonth, A.; Wongstitwilairung, B.; McDaniel, P. and Mason, C.J. (2013): Bacterial pathogens isolated from raw meat and poultry compared with pathogens isolated from children in the same area of rural Thailand. Southest Asian J Trop Med Public Health, 44 (2): 259-272.

Botti, V.; Navillod, F.V.; Domenis, L.; Orusa, R.; Pepe, E.; Robetto, S. and Guidetti, C. (2013): Salmonella spp. and antibiotic-resistant strains in wild mammals and birds in north-western Italy from 2002 to 2010 . Veterinaria Italiana, 49 (2): 195-202.

Boyd, E.F. and Hartl, D.L. (1997): Recent horizontal transmission of plasmids between natural population of E.coli and Salmonella enteric. J. Bacteriol, 179: 1622-1627.

Centro de Referenza Nazionale per le Salmonellosi (2009): (http://www. Izsvenezie.it/images/ stories/pdf/Salmonelle/report_entervet_2009n ew.pdf accessed on 24 October 2012).
Chen, L.; Dubrawski, A.W.; Ray, S.; Baysek, M.; Kelley, L.; Dunham, A.; Huckabee, M.; Fedorke-Cray, P.J.; Jackson, C. And McGlinchey, B. (2008): Detecting linkage between human illness and Salmonella isolates in food using a new tool for spatiotemporal analysis of multi-stream data. AMIA Annu Symp Proc, 6: 900-905.

Chiou, C.S.; Huang, J.F.; Tsai, L.H.; Hsu, K.M.; Liao, C.S. and Chang, H.L. (2006): "A simple and low-cost paper-bridged method for Salmonella phase reversal". Diagnostic Microbiology and Infectious Disease 54 (4): 315-317. doi:10.1016/j.diagmicrobio. 2005. 10.009 .

Dahiya, S.; Kapil, A.; Kumar, R.; Das, B.K.; Sood, S.; Chaudhry, R.; Kabra, S.K. and Lodha, R.K. (2013): Multiple sequence typing of Salmonella Typhi, isolated in north India - a preliminary study. Indian J Med Res, 137: 957-962.

Dziadziuszko, H.; Kumirska, J.; Muza, S.; Czervicka, M.; Lubecka, E.A.; Stepnowski, P. and Kunikowska, D. (2012): Immunochemical studies of Salmonella Dakar and Salmonella Telaviv O-antigens (serogroup O:28). FEMS Microbiol Lett, 326 (1): 55-61.

Echeita, M.A.; Herrera, S.; Garaizar, J. and Usera, M.A. (2002): Multiplex PCR-based detection and identification of the most common Salmonella second-phase flagellar antigens. Res Microbiol, 153 (2): 107-113.

European Food Safety Authority, European Center for Disease Prevention and Control; The European Union. (2012): Summary Report on Trends and Sources of Zoonoses, Zoonotic Agents and Food-borne Outbreaks in 2010. EFSA Journal, 10: 2597-2600.

Ewing, W.H. (1986): Edwards and Ewing's Identification of Enterobacteriacae, 4th ed. Elsevier, New York.

Falkenhorst, G.; Ceper, T.H.; Strid, M.A.; Molbak, $K$. and Krogfelt, K. (2013): Serological follow-up after non-typhoid Salmonella infection in humans using a mixed lippolysaccharide EISA. Int J Med Microbiol, 2 pii: S1438-4221(13)00089-1. doi: 10.1016/ j.ijmm.2013.07.001.

Falkenhorst, G.; Simonsen, J.; Ceper, T.H.; Van Pelt, W.; de Valk, H.; Sadkowska-Todys, M.; Zota, L.; Kuusi, M.; Jernberg, C.; Rota, M.C.; Van Duynhoven, Y.; Teunis, P.; Krogfelt, K. and Molbak, K. (2012): Serological crosssectional studies on Salmonella incidence in eight European countries: no correlation with incidence of reported cases. BMC Public Health, 12: 523.

Graziani, C.; Busani, L.; Dionisi, A.M.; Caprioli, A.; Ivarsson, S.; Hedenstrom, I. and Luzzi, I. (2011): Virulotyping of Salmonella enterica 
serovar Napoli strains isolated in Italy from human and non-human sources. Food borne Pathog Dis, 8: 997-1003.

Grimont, Patrick. (2013): "Antigenic formulae of the Salmonella serovars, 9th edition". WHO Collaborating Centre for Reference and Research on Salmonella. Retrieved 2 July 2013.

Hammack, T.S.; Amaguana, R.M. and Andrews, W.H. (2001): Rappaport-Vassiliadis medium for the recovery of Salmonella from foods with a low microbial load: Collaborative study. J. AOAC Int.84: (1) 65-83.

Hammack, T.S.; Amaguana, R.M.; June, G.A.; Sherrod, P.S. and Andrews. W.H. (1999): Relative effectiveness of selenite cystine broth, tetrathionate broth, and RappaportVassiliadis medium for the recovery of Salmonella from foods with a low microbial load. J. Food Prot. 62: 16-21.

Hernandez, M.; Gomez-Laguna, J.; Tarradas, C.; Lugue, I.; Garcia-Valverde, R.; Reguillo, L. and Astorga, R.J. (2013): A serological survey of Brucella spp., Salmonella spp., and Toxoplasma gondii and Trichnella spp. In Iberian fattening pigs reared in free-range system. Transbound Emerg Dis, 7 doi: 10.1111/tbed.12049.

Hopkins, K.L.; Pinna, E. and Wain, J. (2012): Prevalence of Salmonella enteric serovar 1,4, [5], 12:i:- in England and Wales, 2010. Euro Surveill, 17 (37): pii=20275. http://www. eurosurveillance.org/ViewArticle.aspx?Article $\mathrm{Id}=20275$.

June, G.A.; Sherrod, P.S.; Hammack, T.S.; Amaguana, R.M. and Andrews, W.H. (1995): Relative effectiveness of selenite cystine broth, tetrathionate broth, and RappaportVassiliadis medium for the recovery of Salmonella from raw flesh and other highly contaminated foods: Precollaborative study. J. AOAC Int. 78: 375-380.

June, G.A.; Sherrod, P.S.; Hammack, T.S.; Amaguana, R.M. and Andrews, W.H. (1999): Relative effectiveness of selenite cystine broth, tetrathionate broth, and RappaportVassiliadis medium for the recovery of Salmonella from raw flesh, highly contaminated foods, and poultry feed: Collaborative study. J. AOAC Int. 79: 1307-1323.

Liu, B.; Knirel, Y.A.; Feng, L.; Perpelov, A.V.; Senchenkova, S.N.; Reeves, P.R. and Wang, L. (2013): Structural diversity in Salmonella O antigens and its genetic basis. FEMS Microbiol Rev, doi: 10. 1111/15746976.12034.

Matulova, M.; Havlickova, H.; Sisak, F. and Rychlik, I. (2013): Vaccination of chickens with SPI1Ion and SPI1-Ion-fliC mutant of Salmonella enteric serovar Enteritidis. PLOS ONE, 8 (6): e66172.

Matulova, M.; Rajova, J.; Vlasatikova, L.; Volf, J. and Stepenova, H. (2012): Characterization of chicken spleen transcriptome after infection with Salmonella enteric serovar Enteritidis. PLoS One, 7: e48101.

Matulova, M.; Varmuzova, K.; Sisak, F.; Havlickova, H. and Babak, V. (2013): Chicken innate immune response to oral infection with Salmonella enteric serovar Eneteritidis. Vet Res. 44:37 doi: 10.1186/1297-9716-44-37

Molina-Lopez, R.A.; Valverdu, N.; Martin, M.; Mateu, E.; Obon, E.; Cerda-Cuellar, M. and Darwish, L. (2011): Wild raptors as carriers of antimicrobial-resistant Salmonella and Campylobacter strains. Vet Rec, 168: 565b$567 \mathrm{~b}$.

Much, P.; Pichler, J.; Kasper, S.S. and Allerberger, F. (2009): Foodborne outbreaks, Austria 2007. Wien Klin Wochenschr., 12 (3-4): 77-85.

Murray, PR.; Baron, EJ.; Pfaller, MA.; Tenover, FC. Yolken, RH. (1995): Manual of Clinical Microbiology. Washington, DC: ASM Press.

Office International des Epizooties: OIE (World Organization for Animal Health). (2010): Salmonellosis. OIE Terrestrial Manual, Chapter 2.9.9.

Oloya, J.; Doetkott, D. and Khaitsa, M.L. (2009): Antimicrobial drug resistance and molecular characterization of Salmonella isolated from domestic animals, humans and meat products. Foodborne pathog Dis., 6(3): 273-284

Ovchinnikova, O.G.; Rozalski, A.; Liu, B. and Knirel, $Y$.A. (2013): O-antigens of bacteria of the genus providencia: structure, serology, genetics and biosynthesis. Biochemistry (Mosc), 78 (7): 798-817.

Pang, J.C.; Chiu, T.H.; Helmuth, R.; Schroeter, A.; Guerra, B. And Tsen, H.Y. (2007): A pulsed field gel electrophoresis (PFGE) study that suggests a major world-wide clone of Salmonella enteric serovar Enteritidis. Int. J. Food Microbiol, 116 (3): 305-312.

Popoff, M.Y. (2001): Le Minor L. Antigenic formulas of the Salmonella serovars, 8th revision, World Health Organization Collaborating Centre for Reference and Research on Salmonella, Pasteur Institute, Paris, France.

Rios, R.M.; Araya, R.P.; Fernandez, R.A.; Tognarelli, J.; Hormazabal, J.C. and Fernandez, O.J. (2009): Molecular subtyping of Salmonella enteric serotype Enteritidis in a post epidemic period. Rev Med Chil, 137 (1): 71-75.

Rotger, R. and Casadesus, J. (1999): The virulence plasmids of Salmonella. Internatl Microbiol, 2: 177-184.

Tennant, S.M.; Diallo, S.; levy, H.; Livio, S.; Sow, S.O. and Tapia, M. (2010): Identification by 
PCR of non-typhoidal Salmonella enteric serovars associated with invasive infections among febrile patients in Mali. PLoS Negl Trop Dis, 4: e621.

Toboldt, A.; Tietze, E.; Helmuth, R.; Fruth, A.; Junker, E. and Malorny, B. (2012): Human infections attributable to the D-tartaratefermenting variant of Salmonella enteric serovar Paratyphi B in Germany originate in reptiles and, on rare occasions, poultry. Appl Envirn Microbiol, 78 (20): 7347-7357.

Van der Fels-Klerx, H.J.; Tromp, S.; Rijgersberg, $H$. and Van Asselt, E.D. (2008): Application of a transmission model to estimate performance objectives for Salmonella in the broiler supply chain. Int. J. Food Microbiol, 128 (1): 22-27.

Van Parys, A.; Boyen, F.; Leyman, B.; Verbrugghe, E.; Maes, D.; Haesebrouck, F. and Pasmans, F. (2013): Induction od seroconversion and persistence of Salmonella Typhimurium in pigs are strain dependent. Comp Immunol Microbiol Infect Dis, 36 (5): 465-471.
Wasyl, D. and Hoszowski, A. (2012): Occurrence and characterization of monophasic Salmonella enteric serovar typhimurium (1,4, [5], 12:i:-) of non-human origin in Poland. Food borne Pathol Dis, 9 (11): 1037-1043.

Williams and Wilkins (1984): Le Minor L. Genus III Salmonella. In: Krieg NR, Holt JG, Editors. Bergey"s Manual of Systematic Bacteriology, vol. 1, Baltimore, P. 427.

Yang, J.C.; Xia, Y.; Guo, H.; Xu, J.J.; Wang, L.M.; Tong, J.; Zhang, L.; Liang, J.R.; Jing, H.Q. and Li, Z.J. (2013): An etiological survey on a food borne disease epidemic outbreak caused by Salmonella enteritidis. Zhonghua Yu Fang Yi Xue Za Zhi, 47 (2): 160-163.

Yang, $X$.; Wu, Q.; Zhang, J.; Dong, $X$. and Liu, S. (2013): Biochemical and serological characterization of Salmonella from retail meats in Guangdong province. Wei Sheng Yan Jiu, 42 (4): 615-618.

\section{التصنيف السيرولوجى لعترات السالمونيلا فى منتجات اللحوم والدواجن \\ Email: Karmy99@yahoo.com, mkarmi@aswu.edu.eg.}

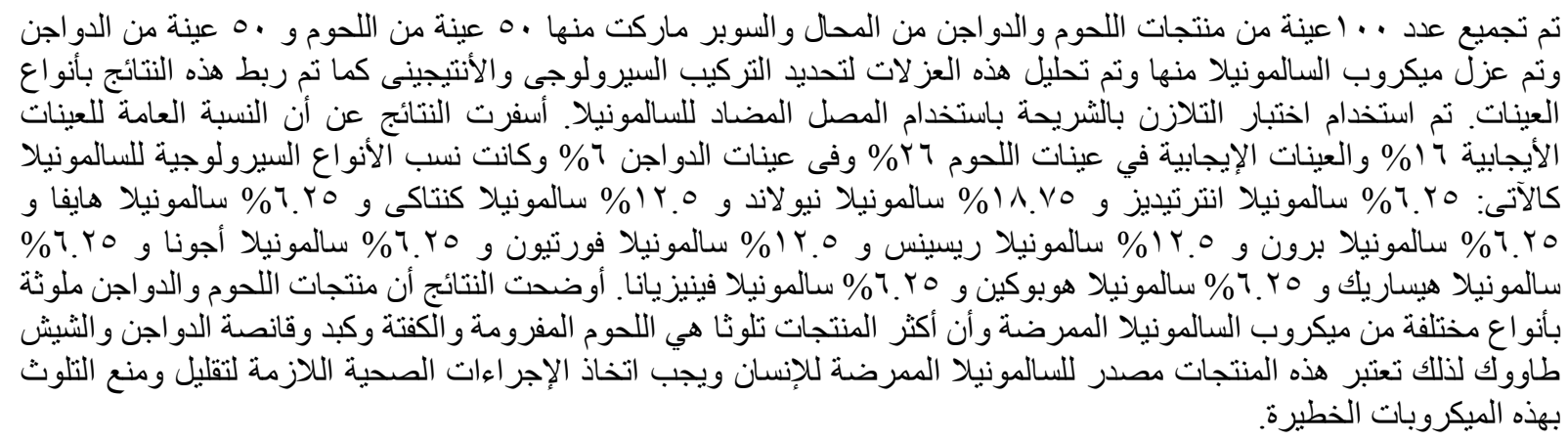

